\title{
Protein kinases orchestrate cell cycle regulators in differentiating BeWo choriocarcinoma cells
}

\author{
M. Naveen Kumar ${ }^{1} \cdot$ R. L. Babu ${ }^{2,3} \cdot$ Rajeshwari H. Patil $^{1,4} \cdot$ K. M. Kiran Kumar ${ }^{1} \cdot$ Shubha M. Hegde $^{1} \cdot$ Rashmi Nagesh $^{1}$. \\ K. Kavya ${ }^{1} \cdot$ Govindarajan T. Ramesh $^{3} \cdot$ S. Chidananda Sharma ${ }^{1}$. C. Srinivas ${ }^{1}$
}

Received: 12 March 2018 / Accepted: 13 July 2018 / Published online: 26 July 2018

(c) Springer Science+Business Media, LLC, part of Springer Nature 2018

\begin{abstract}
Choriocarcinoma, a trophoblastic neoplasia, occurs in women as an incidence of abnormal pregnancy. BeWo choriocarcinoma cells derived from the abnormal placentation are a suitable model system to study the factors associated with differentiation, invasion and other cellular events as an alternative to clinical samples. Many protein kinases orchestrate the complex events of cell cycle and in case of malignancy such regulators are found to be mutated. In the present study, BeWo cells treated with forskolin (Fo) and phorbol 12-myristate 13-acetate (PMA) were used to study the role of PKA (protein kinase A) and PKC (protein kinase C), respectively, on the expression pattern of differentiation-related genes, membrane markers, PKC isoforms and cell cycle regulators. The effect of Fo and PMA on the cell proliferation was assessed. Progressive induction of alkaline phosphatase level and formation of multinucleated differentiated cells were observed in the cells treated with Fo. Exposure of cells to Fo and PMA induced the mRNA transcripts of $\alpha$-hCG, $\beta$-hCG and endoglin and down-regulates E-cadherin at mRNA and protein levels. Synergistic levels of both up- and down-regulated genes/proteins were observed when cells were treated with the combination of Fo and PMA. The mRNA levels of cyclin D1, cyclin E1, p21, Rb, p53, caspase-3 and caspase- 8 decreased gradually during differentiation. Fo significantly inhibited the protein levels of PCNA, Rb, PKC- $\alpha$ and PMA stimulated mRNA expression of PKC- $\varepsilon$ and PKC- $\delta$. Further, failure in the activation of essential components of the cell cycle machinery caused G2/M phase arrest in differentiating BeWo cells.
\end{abstract}

Keywords BeWo choriocarcinoma cells $\cdot$ Cell cycle $\cdot$ Differentiation $\cdot$ Forskolin $\cdot$ Phorbol esters $\cdot$ Protein kinases

C. Srinivas

csrinivas@bub.ernet.in; srinivasbub@gmail.com

M. Naveen Kumar

naveenbio10@gmail.com

1 Department of Microbiology and Biotechnology, Bangalore University, Jnana Bharathi Campus, Bengaluru 560 056, Karnataka, India

2 Department of Bioinformatics and Biotechnology, Akkamahadevi Women's University, Jnanashakthi Campus, Vijayapura 586 108, Karnataka, India

3 Department of Biology and Center for Biotechnology and Biomedical Sciences, Norfolk State University, Norfolk, VA, USA

4 Present Address: Department of Molecular Reproduction, Development and Genetics, Indian Institute of Science, Bengaluru 560 012, Karnataka, India

\section{Introduction}

Choriocarcinoma, a gestational trophoblastic neoplasia, occurs in women as a placental disorder. Gestational trophoblastic disease (GTD) develops with failure in common regulatory mechanisms of cells which leads to benign hydatidiform mole, malignant choriocarcinoma, invasive mole or placental site trophoblastic tumour [1,2]. GTD causes adverse pregnancy outcome including placental abruption, preeclampsia, preterm birth and intrauterine growth restriction [3]. Unlike other forms of GTD, choriocarcinoma initially localized in the uterus and aggressive neoplasm gradually spreads to the other organs, viz. lung, liver and brain, and remain fatal if untreated $[4,5]$. Gestational choriocarcinoma produces high levels of $\beta$-hCG (human chorionic gonadotropin) even in the absence of embryo. Gestational choriocarcinoma responds to chemotherapy with a cure rate of $80 \%[6,7]$. Despite a markedly improved prognosis because of chemotherapy, a substantial proportion of patients with 
choriocarcinoma continue to succumb to the disease. The relative rarity of the incidence and clinical background make it difficult to obtain sufficient samples for investigation of the disease [8]. Hence, choriocarcinoma cell lines derived from human spontaneous choriocarcinoma are widely used to study molecular mechanisms underlying syncytialization, adhesion and migration due to constraint use of in vivo samples [9].

Trophoblast is considered as a specialized structure having the characteristics of an epithelial cell, involved in the exchange of gases, nutrients and waste across the maternal-foetal interface [10]. The human trophoblast is characterized by a tightly controlled programme of cell proliferation, differentiation, invasion, angiogenesis and apoptosis [11]. During the initial phase of human trophoblast differentiation, the cytotrophoblast cells fuse to form multinucleated syncytiotrophoblasts and largely express human placental lactogen, alkaline phosphatase, hCG, endoglin and syncytin following the repression of E-cadherin in differentiated cells [12-16]. The formation of syncytium, characterized as multiple nuclei sharing one cytoplasm, is the most important hallmark of cytotrophoblast differentiation [17, 18]. However, the mechanism by which villous cytotrophoblast undergoes intercellular fusion and functional differentiation is not clear, although there is unsurpassed evidence that supports the involvement of hormones, growth factors, cytokines, membrane proteins, protein kinases, intracellular proteases and transcription factors [19]. Many protein kinases orchestrate the complex events of cell cycle and differentiation, but in malignancy most of the regulator genes are mutated and exhibit altered levels of mRNA and protein expression [20]. Such changes contribute to deregulation of cell cycle and altered activity of kinases or phosphatases associated with epithelial-mesenchymal transition, aberrant cell division and proliferation [21]. Different phases of cell division (G1, $\mathrm{S}, \mathrm{G} 2$ and M) function as an intricate system that safeguard as cell cycle checkpoints. The phases are mediated mainly by cyclins, cyclin-dependent kinases (CDK), Rb, p53 and E2F proteins. CDKs are also controlled by the family of CDK inhibitory proteins (INK4) and kinase inhibitory proteins (KIP) [22, 23].

In placental choriocarcinoma cells, syncytiotrophoblast formation is a downstream fusogenic event and the cascade is believed to begin with increased cyclic AMP (cAMP) levels, which occurs via the activation of adenylyl cyclase and the consequent activation of PKA (protein kinase A) that resembles the in vivo trophoblast cell differentiation. Forskolin (Fo), an activator of adenylyl cyclase, is used to induce the differentiation of in vitro cell models [24]. The role of cAMP in cell cycle growth and cancer development is well established with various cancer cell types [25]. The effects of gonadotropins on ovarian cell proliferation and differentiation are mediated by changes in intracellular cAMP that activates PKA [26]. Hormonal cAMP regulation of ERK cascade provides an important crosstalk between hormones and growth factor signaling [27]. The cAMP appears to act as both an activator as well as an inhibitor of cell proliferation [28] and effects the production of a variety of proteins including hormones, enzymes, cellular oncogenes and extracellular matrix proteins. Researchers from various laboratories reported that cAMP inhibits the cell growth of adipocytes [29], endothelial cells [30], NIH 3T3 cells [31] and hepatocytes [32] by blocking the activation of ERKs and cascades. The cAMP is also shown to activate multiple intracellular signalling cascades independent of its activation of PKA [28]; however, most of the studies examining cAMP inhibition of ERKs show the requirement for PKA [29-31].

Protein kinase C (PKC), a superfamily of serine/threonine kinases and its isoenzymes, has been shown to display variable expression profiles during cancer progression. PKC isoenzymes are classified into conventional $(\alpha, \beta$ and $\gamma)$, novel $(\delta, \varepsilon, \eta$ and $\theta)$ and typical $(\mu, \xi$ and $\tau$ ) forms based on the differences in their $\mathrm{N}$-terminal regulatory domain [33]. PKCs have been traditionally viewed as lipid-sensitive enzymes activated by growth factor and its receptors. PKCs are pharmacologically activated by phorbol esters such as phorbol 12-myristate 13-acetate (PMA), which anchors PKC in their active conformation. Thus, the activation of different types of PKCs depends on the different cellular responses and cross-talks between PKC isoenzymes are specific for particular cell types [34]. PMA stimulates the differentiation of leukaemia cells via activation of MAPK kinase/ERK signaling pathway $[35,36]$ and used as an agent in 'differentiation therapy', a promising strategy for cancer treatment [37]. In intestinal epithelial cells, PKC- $\alpha$ exerts anti-proliferative action in association with ERK activation by inhibiting p21 and p27 during the G1 phase of cell cycle [38]. PKC- $\delta$ down-regulates the expression of cyclins causing G1 and G2 phase of cell cycle arrest in lung adenocarcinoma cells $[39,40]$. Earlier reports demonstrate the PMA-induced differentiation and production of hCG with the involvement of signal transduction pathways [41] and the activation of both PKA and PKC results in a synergistic increase in the transcription of $\alpha$ and $\beta$ subunits of hCG in choriocarcinoma cell lines [42, 43]. Although several reports on the role of PKA and PKC in choriocarcinoma are available, the multiple signal transduction pathways involving different types of protein kinases during the differentiation of cytotrophoblast to syncytiotrophoblast are less understood. Hence, in the present study Fo is used to induce the differentiation of human choriocarcinoma cells. Further, the role of PKA activated by Fo and PKC by PMA on the expression pattern of differentiation-related genes/proteins, membrane markers and PKC isoforms and their effects on different cell cycle regulators in BeWo cells are investigated. 


\section{Materials and methods}

\section{Materials}

Nutrient mixture F-12 Ham Kaighn's medium (Ham's F-12K), fetal bovine serum (FBS), penicillin, streptomycin, glutamine, dimethyl sulfoxide (DMSO), trypsin, trypan blue, 3-(4,5-dimethythiazol-2-yl)-2,5-diphenyl tetrazolium bromide (MTT), phenol, DEPC (diethyl pyrocarbonate), sodium acetate, chloroform, isopropyl alcohol, Tris base, EDTA, glacial acetic acid, formaldehyde, Tris-HCl, glycerol and ethidium bromide were purchased from HiMedia (Mumbai, India). Bromophenol blue, acrylamide and bis-acrylamide were procured from Sisco Research Laboratories Pvt. Ltd. (Mumbai, India). T-25 and T-75 culture flasks, 6-well and 96-well culture plates and PCR tubes were purchased from Tarsons (Bengaluru, India). TRIzol reagent, secondary anti-rabbit/ mouse antibodies and oligo forward and reverse primers (Table 1) were designed and were purchased from SigmaAldrich (St Louis, USA). Oligo dTs and Superscript III First-Strand cDNA Synthesis kit were obtained from Invitrogen BioServices India Pvt. Ltd. (Bengaluru, India). Taq DNA polymerase $(1 \mathrm{U} / \mu \mathrm{L})$ and Luminata Forte Western HRP substrate were procured from Merck-Millipore (Mumbai, India).

\section{Methods}

\section{Culturing of BeWo cells}

BeWo cells (human choriocarcinoma cell line was a kind gift by Prof. Satish Kumar Guptha, Reproductive Cell Biology Laboratory, National Institute of Immunology, New Delhi, India and was originally procured from American Type Culture Collection, VA, USA) were cultured with or without
Table 1 Sequence of primers (F: forward and R: reverse) used for the amplification of genes

\begin{tabular}{|c|c|c|c|}
\hline Gene & Primer sequence $\left(5^{\prime} \rightarrow 3^{\prime}\right)$ & $\begin{array}{l}\text { Annealing } \\
\text { temp. }\left({ }^{\circ} \mathrm{C}\right)\end{array}$ & $\begin{array}{l}\text { Product } \\
\text { size }(b p)\end{array}$ \\
\hline$\alpha$-hCG & $\begin{array}{l}\text { F: GAGAAAGGAGCGCCATGGAT } \\
\text { R: ACAAGTACTGCAGTGGCACG }\end{array}$ & 61.5 & 347 \\
\hline$\beta$-hCG & $\begin{array}{l}\text { F: GTTCCAGGGGCTGCTGCTGTT } \\
\text { R: CGGGAGTCGGGATGGGCTTGG }\end{array}$ & 64 & 457 \\
\hline E-cadherin & $\begin{array}{l}\text { F: CGCATTGCCACATACA } \\
\text { R: CGTTAGCCTCGTTCTCA }\end{array}$ & 56 & 502 \\
\hline Endoglin & $\begin{array}{l}\text { F: CGTGGACTGGTTAGTTGA } \\
\text { R: AGGCTGTCCATGTTGAGGCAGT }\end{array}$ & 55 & 416 \\
\hline $\mathrm{PKC} \varepsilon$ & $\begin{array}{l}\text { F: CTTCTCGACCCCTACATTGCC } \\
\text { R: GCAGGTGCAGACTTGACACTG }\end{array}$ & 61 & 449 \\
\hline PKC $\delta$ & $\begin{array}{l}\text { F: CTGCAAGAAGAACAATGGCAAG } \\
\text { R: ATCCACGTCCTCCAGGAAATACT }\end{array}$ & 62 & 96 \\
\hline p53 & $\begin{array}{l}\text { F: GAGCCCCCTCTGAGTCAG } \\
\text { R: GCAAAAACATCTTGTTGAG }\end{array}$ & 56 & 375 \\
\hline $\mathrm{Rb}$ & $\begin{array}{l}\text { F: AAGTACCCATCTAGTACT } \\
\text { R: AAGTTACAGCATCTCTAAA }\end{array}$ & 58 & 547 \\
\hline p21 & $\begin{array}{l}\text { F: GATCACAAGCAGTGGGGTGA } \\
\text { R: CTGAGTGACTGCACGACCTT }\end{array}$ & 58 & 160 \\
\hline CDK-4 & $\begin{array}{l}\text { F: AGTGGCGGATCCATGGCTACCTCTCGATAT } \\
\text { R: TCTCGGAAGCTTTCACTCCGGATTACCTTCA }\end{array}$ & 60 & 912 \\
\hline Cyclin D1 & $\begin{array}{l}\text { F: AGACCTGCGCGCCCTCGGTG } \\
\text { R: GTAGTAGGACAGGAAGTTGTTG }\end{array}$ & 58 & 574 \\
\hline Cyclin E1 & $\begin{array}{l}\text { F: GTCCTGGCTGAATGTATACATGC } \\
\text { R: CCCTATTTTGTTCAGACAACAT }\end{array}$ & 60 & 415 \\
\hline Caspase- 8 & $\begin{array}{l}\text { F: GATATTGGGGAACAACTGGAC } \\
\text { R: CATGTCATCATCCAGTTTGCA }\end{array}$ & 58 & 366 \\
\hline Caspase-3 & $\begin{array}{l}\text { F: TTAATAAAGGTATCCATGGAGAACACT } \\
\text { R: TTAGTGATAAAAATAGAGTTCTTTTGTGAG }\end{array}$ & 59 & 848 \\
\hline$\beta$-actin & $\begin{array}{l}\text { F: TACCACTGGCATCGTGATGGACT } \\
\text { R: TCCTTCTGCATCCTGTCGGCAAT }\end{array}$ & 62 & 516 \\
\hline
\end{tabular}

Columns 3 and 4 show the different annealing temperatures used and the size of the amplified products, respectively 
serum in Ham's F-12K medium supplemented with $10 \%$ FBS, penicillin $(100 \mathrm{u} / \mathrm{mL})$ and streptomycin $(100 \mathrm{u} / \mathrm{mL})$ under the atmosphere of $5 \% \mathrm{CO}_{2}$ and $95 \%$ air in a humidified incubator at $37^{\circ} \mathrm{C}$. The $25 \mathrm{~cm}^{2}$ culture flask containing 80-90\% confluent cells were subcultured into a 96 -well plate $\left(3 \times 10^{3}\right.$ cells/well $)$ or a 6 -well plate $\left(3 \times 10^{5}\right.$ cells/well $)$ for the experimental studies.

\section{Differentiation of BeWo cells}

BeWo cells were cultured in Ham's F-12K medium supplemented with $10 \% \mathrm{FBS}$ for $24 \mathrm{~h}$ in a $\mathrm{CO}_{2}$ incubator. For induction of differentiation, the cells were serum starved for $4 \mathrm{~h}$. Further, cells were treated with Fo $(50 \mu \mathrm{M})$ in serumfree Ham's F-12K medium supplemented with 1X ITS solution containing final concentrations of insulin $(10 \mu \mathrm{g} / \mathrm{mL})$, transferrin $(5.5 \mu \mathrm{g} / \mathrm{mL})$, selenium $(0.005 \mu \mathrm{g} / \mathrm{mL})$ and BSA $(500 \mu \mathrm{g} / \mathrm{mL})$ for different time periods $(24,48$ and $72 \mathrm{~h})$.

\section{Assessment of cell viability}

The cell viability assay was carried out using MTT as per the protocol described earlier [44] with modifications. BeWo cells $\left(3 \times 10^{3}\right.$ cells/well) were cultured in a 96-well plate in Ham's F-12K medium and incubated for $24 \mathrm{~h}$ in $\mathrm{CO}_{2}$ incubator prior to exposure for experimental conditions. At the end of experiment $50 \mu \mathrm{L}$ of MTT solution $(2 \mathrm{mg} / \mathrm{mL})$ was added to each well and incubated further for $4 \mathrm{~h}$ at $37^{\circ} \mathrm{C}$ in $\mathrm{CO}_{2}$ incubator. The formazan product formed in cells was dissolved using DMSO $(100 \mu \mathrm{L})$ and the absorbance was measured at $540 \mathrm{~nm}$ using PerkinElmer Multimode plate reader (MA, USA).

\section{Alkaline phosphatase assay}

BeWo cells $\left(3 \times 10^{5}\right.$ cells/well $)$ were cultured in a 6-well culture plate in Ham's F-12K medium and incubated for $24 \mathrm{~h}$ in a $\mathrm{CO}_{2}$ incubator. Cells were treated with $\mathrm{Fo}(50 \mu \mathrm{M})$ for 24, 48 and $72 \mathrm{~h}$ in serum-free Ham's F-12K medium supplemented with $1 \mathrm{X}$ ITS solution. After each time point, the conditioned medium was removed, cells were washed with $\mathrm{PBS}$, cell lysate was prepared using lysis buffer [Tris-HCl (50 mM, pH 8.0), $\mathrm{NaCl}(150 \mathrm{mM})$, Triton X-100 (0.1\%) and PMSF $(100 \mu \mathrm{M})]$ and total protein concentration was measured by Bradford method [45]. Alkaline phosphatase (ALP) expressed in the control and treated cells was analysed using p-nitrophenylphosphate (p-NPP) according to the method described earlier [46] with modifications and the activity was expressed per mg protein. The sample containing ALP which results in the appearance of yellow colour was measured spectrophotometrically at $405 \mathrm{~nm}$ using a PerkinElmer Multimode plate reader (MA, USA).

\section{RNA isolation and RT-PCR}

BeWo cells were treated with Fo $(50 \mu \mathrm{M})$ for 24,48 and $72 \mathrm{~h}$ and in another set of experiments Fo with or without PMA $(10 \mathrm{nM})$ was treated for $72 \mathrm{~h}$ by keeping appropriate vehicle control. After each time point, the conditioned medium was removed and total RNA was isolated using TRI Reagent as per the manufacturer's protocol (Sigma-Aldrich). The quality and concentration of RNA isolated were assessed on $1 \%$ MOPS-formaldehyde gel. Further, RT-PCR analysis was carried out as per the protocol described earlier [47]. In brief, equal concentrations of total RNA $(2 \mu \mathrm{g})$ from the control and treated samples were reverse transcribed. The cDNA obtained was subjected to PCR using forward and reverse primers of respective genes (Table 1). Amplified PCR products were analysed by agarose gel electrophoresis. Relative mRNA levels were quantified using image analysis software (ImageJ—https://imagej.nih.gov/ij/).

\section{Western blot analysis}

BeWo cells were treated with Fo $(50 \mu \mathrm{M})$ for 24,48 and $72 \mathrm{~h}$ and in another set of experiments Fo with or without PMA $(10 \mathrm{nM})$ was treated for $72 \mathrm{~h}$ by keeping appropriate vehicle control. After each time point, the conditioned medium was removed and total protein was isolated using cell lysis buffer. Protein concentration was measured by Bradford's method [45] and subjected to western blot analysis as described earlier [48]. Equal concentrations of protein $(40 \mu \mathrm{g} / \mathrm{lane}) \mathrm{sam}$ ples were electrophoresed on SDS-PAGE and transferred onto a PVDF membrane. Membrane was blocked for $2 \mathrm{~h}$ and incubated with primary antibody (1:500 dilutions of rabbit anti- $\beta$-hCG/ALP/PKC- $\alpha / \mathrm{Rb}$ and $1: 1000$ dilution of mouse anti-E-cadherin/PCNA/GAPDH) overnight at $4{ }^{\circ} \mathrm{C}$. Further, the membrane was washed using TBST, incubated with anti-rabbit/mouse secondary antibody-HRP (1:1000) for $2 \mathrm{~h}$ and washed 3-4 times. Protein bands were visualized using a Luminata Forte Western HRP substrate in a Syngene Gel Documentation system (MD, USA) and quantified using image analysis software (ImageJ-https://imagej.nih. gov/ij/) [ $\beta$-hCG, ALP and PKC- $\alpha$ antibodies were procured from neobiolab (MA, USA) and Rb was procured from Santa Cruz Biotech (CA, USA). PCNA and GAPDH antibodies are kind gift by Prof. A. J. Rao, Dept. of Biochemistry and E-cadherin by Prof. Annapoorni Rangarajan, Dept. of MRDG, IISc, Bengaluru].

\section{Cell cycle analysis}

BeWo cells were treated with or without Fo and PMA for $72 \mathrm{~h}$. Flow cytometry analysis was performed as previously described [49]. Cells were harvested, washed with PBS and fixed in $70 \%$ cold ethanol for $1 \mathrm{~h}$. Further, cells were washed 
with PBS and suspended in RNase solution $(200 \mu \mathrm{g} / \mathrm{mL})$ for 30 min incubation at $37^{\circ} \mathrm{C}$. The samples were stained with propidium iodide (PI) $(50 \mu \mathrm{g} / \mathrm{mL})$ and analyzed using a Becton Dickinson FACS Accuri 6 plus flow Cytometry system.

\section{Statistical analysis}

The experimental data are shown as mean \pm standard deviation from three independent experiments. Statistical analyses were done by Student's $t$ test and one-way ANOVA followed by Tukey's post hoc test. Values were considered statistically significant at $* P<0.05$ and $* * P<0.005$ compared to control, ${ }^{\#} P<0.05$ compared to Fo-treated sample and ${ }^{\$} P<0.05$ when compared to PMA-treated sample.

\section{Results}

\section{Forskolin decreases the proliferation of BeWo cells with increase in time intervals}

To study the effect of Fo on cell proliferation, BeWo cells were treated with or without Fo and PKA inhibitor. Cells treated with 1 and $10 \mu \mathrm{M}$ Fo showed a maximum increase in the proliferation of about 12 and 5\%, respectively, at 24 and $48 \mathrm{~h}$. The cell number gradually decreased and attained the level of control at $24 \mathrm{~h}$ and a significant decrease of $10 \%$ in the cell number was observed at $100 \mu \mathrm{M}$ at the time point of $48 \mathrm{~h}$. In cells treated for $72 \mathrm{~h}$, proliferation was decreased in a dose-dependent manner and a statistically significant decrease of $30 \%$ was observed at $100 \mu \mathrm{M}$ concentration of Fo (Fig. 1a). PKA inhibitor alone was found to have no effect on the cell growth. However, an increase in the proliferation was observed in the cells treated with Fo + PKA inhibitor compared to the cells treated with Fo alone (Fig. 1b).

\section{PMA decreases the proliferation of BeWo cells}

To study the effect of PMA on cell growth, BeWo cells were treated with different concentrations of PMA. Cell proliferation was decreased with increase in the concentration and statistically a significant decrease of $10 \%$ at $10 \mathrm{nM}$ and an almost $20 \%$ decrease in cell proliferation were observed at higher PMA concentrations $(100 \mathrm{nM}$ and $1 \mu \mathrm{M})$ (Fig. 2).

\section{Forskolin induces alkaline phosphatase in BeWo cells}

To confirm the action of Fo-mediated differentiation in BeWo cells, the alkaline phosphatase activity was measured. In the presence of Fo $(50 \mu \mathrm{M})$, cellular alkaline phosphatase level increased significantly with an increase in the time interval compared to control. The cells treated with Fo alone induce the ALP level by 18 and $62 \%$ at 24 and $48 \mathrm{~h}$, respectively. Progressively, the exposure of cells to Fo for $72 \mathrm{~h}$ show time-dependent induction of ALP enzyme level (Fig. 3a) and a twofold increase in ALP protein expression was also observed at $72 \mathrm{~h}$ (Fig. 3b).

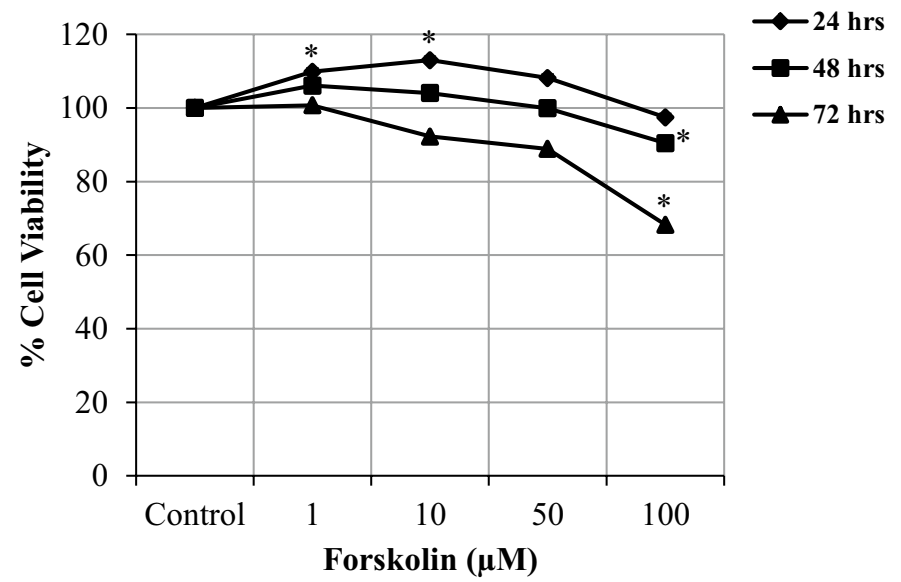

(a)

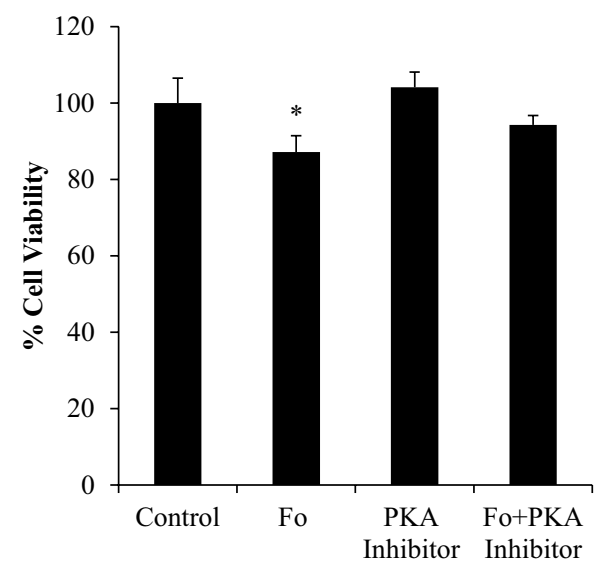

(b)

Fig. 1 Effect of Fo on the proliferation of BeWo cells. BeWo cells $\left(3 \times 10^{3}\right.$ cells/well $)$ were treated with or without different concentrations of a Fo $(1-100 \mu \mathrm{M})$ for different time intervals (24, 48 and $72 \mathrm{~h}$ ) and in another group; b cells were treated with Fo alone $(50 \mu \mathrm{M})$, PKA inhibitor $(0.1 \mu \mathrm{M})$ alone and Fo + PKA inhibitor for $72 \mathrm{~h}$ and

cell growth was measured by MTT assay. Results were expressed as $\%$ cell viability compared to control (mean $\pm \mathrm{SD}, n=4)$. Values are significantly different from control at $* P<0.05$ as analysed using Student's $t$ test 


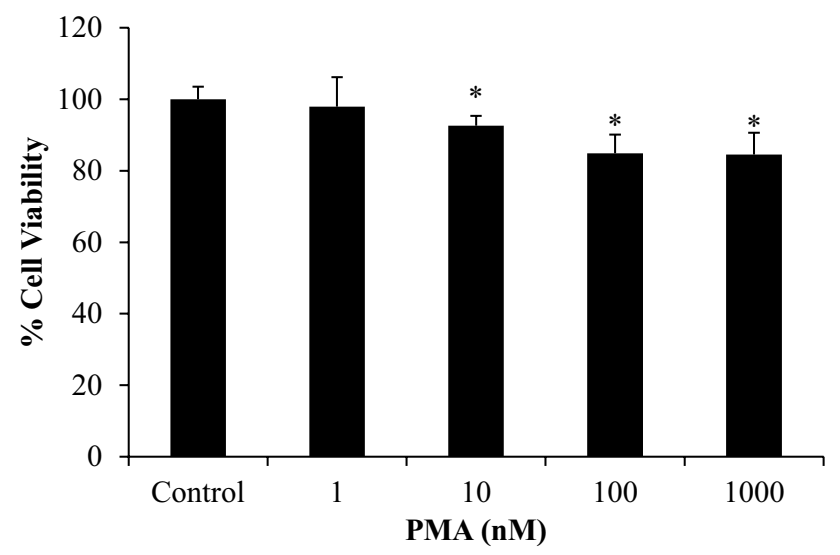

Fig. 2 Effect of PMA on the proliferation of BeWo cells. BeWo cells $\left(3 \times 10^{3}\right.$ cells/well $)$ were treated with or without different concentrations of PMA $(1 \mathrm{nM}-1 \mu \mathrm{M})$ in a 96-well plate for $72 \mathrm{~h}$ and cell growth was measured by MTT assay. Results were expressed as \% cell viability compared to control (mean $\pm \mathrm{SD}, n=4)$. Values are significantly different from control at $* P<0.05$ as analysed using Student's $t$ test

\section{Forskolin induces $\boldsymbol{\alpha}$-hCG, $\boldsymbol{\beta}$-hCG and endoglin and down-regulates E-cadherin mRNA expression in BeWo cells}

To assess the effect of Fo on the differentiation of BeWo cells, the mRNA levels of $\alpha$-hCG, $\beta$-hCG, endoglin and E-cadherin were analysed by semi-quantitative RT-PCR. BeWo cell differentiation is associated with increased synthesis and secretion of hCG. Choriocarcinoma cells show increasing amounts of hCG in response to Fo. The cells treated with Fo $(50 \mu \mathrm{M})$ induced $\alpha$-hCG mRNA expression 2.1 -fold at $24 \mathrm{~h}$ and remain almost similar to the 72 -h treatment. However, a time-dependent increase in the mRNA levels of $\beta$-hCG and endoglin was observed and a maximum increase of 4.3- and 1.3-fold was observed at $72 \mathrm{~h}$ when compared to control (Fig. 4a). E-cadherin, a cell adhesion molecule, was down-regulated by 15 and $42 \%$ at 24 and $72 \mathrm{~h}$, respectively, in the fusing cells (Fig. 4a). Further, microscopic observations of multinucleated cells confirm the differentiation of BeWo cells (Fig. 4b).

\section{Down-regulation of PKC- $\varepsilon$ and PKC- $\delta$ transcripts in differentiating BeWo cells}

BeWo cells treated with Fo to confirm its action on the mRNA expressions of PKC- $\varepsilon$ and $\delta$. Cells treated with Fo progressively inhibit the expression of both PKC- $\varepsilon$ and $\delta$ mRNAs. Initially, at the 24-h time point PKC- $\varepsilon$ shows marginal induction and decline in expression at the 72-h time point by $60 \%$ compared to the 0 -h treatment. In contrast, Fo down-regulates PKC- $\delta$ mRNA levels in a time-dependent manner with a maximum decrease of $32 \%$ at $72 \mathrm{~h}$ (Fig. 5).

\section{Forskolin regulates mRNA expression of cell cycle regulators in BeWo cells}

To study the effect of Fo on apoptotic and cell cycle regulators in BeWo cells, the mRNA levels were analysed by semi-quantitative RT-PCR. Cells treated with Fo for different time intervals progressively down-regulates the mRNA expressions of CDK-4, p21, p53, Rb and caspase-3 in a time-dependent manner. However, cyclin D1, cyclin E1 and caspase- 8 were induced initially at the 24 -h time point and the increase in treatment time gradually reduced their expression compared to the control cells (Fig. 6). Cyclin D1 and cyclin E1 mRNA levels were induced by 22 and $16 \%$ at $24 \mathrm{~h}$ and 16 and $10 \%$ at $48 \mathrm{~h}$, respectively. Further, at $72 \mathrm{~h}$, the mRNA levels of cyclin D1 and cyclin E1 decreased to 12 and $6 \%$, respectively, compared to control.
Fig. 3 Effect of forskolin on alkaline phosphatase a enzyme activity and $\mathbf{b}$ protein expression in BeWo cells. BeWo cells $\left(3 \times 10^{5}\right.$ cells/well $)$ were treated with or without Fo (50 $\mu \mathrm{M})$ for different time intervals (24, 48 and 72 h). Results were expressed as alkaline phosphatase activity/mg protein and as relative expression compared to control (mean $\pm \mathrm{SD}, n=3$ ). Values are significantly different from control at $* * P<0.05$ as analysed using one-way ANOVA followed by Tukey's post hoc test

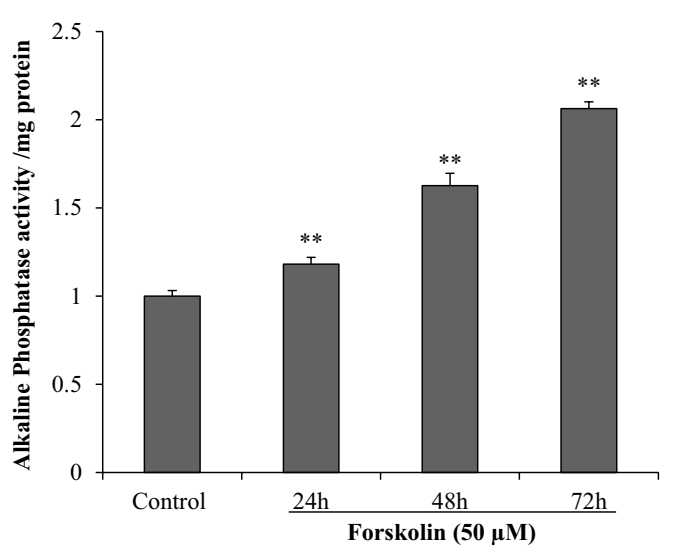

(a)

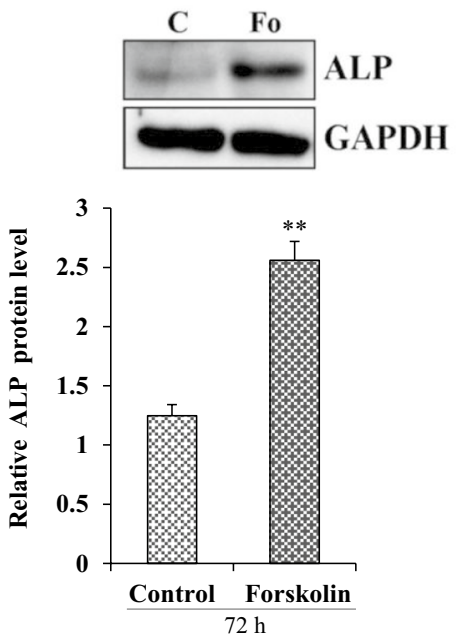

(b) 
Fig. 4 Effect of Forskolin on a the expression of $\alpha$-hCG, $\beta$-hCG, endoglin and E-cadherin and $\mathbf{b}$ the morphology of differentiating BeWo cells. BeWo cells $\left(3 \times 10^{5}\right.$ cells/well $)$ were treated with Fo $(50 \mu \mathrm{M})$ for different time intervals. The expressions of amplified genes were analysed on $1 \%$ agarose gel and $\beta$-actin was used as a positive control and for normalization. The bar graph represents the densitometric analysis of mRNA levels (mean $\pm \mathrm{SD}$, $n=3$ ). Differences in mRNA levels are statistically significant at $* P<0.05$ compared with 0 -h values as analysed using one-way ANOVA followed by Tukey's post hoc test
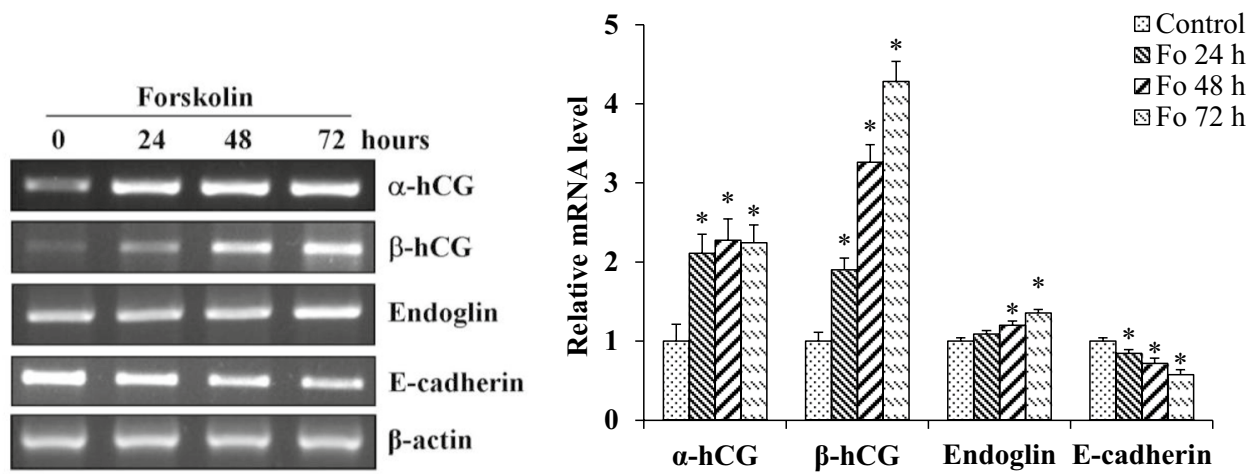

(a)

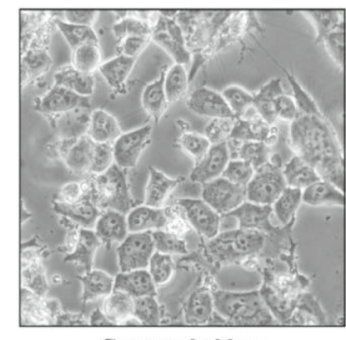

Cytotrophoblast

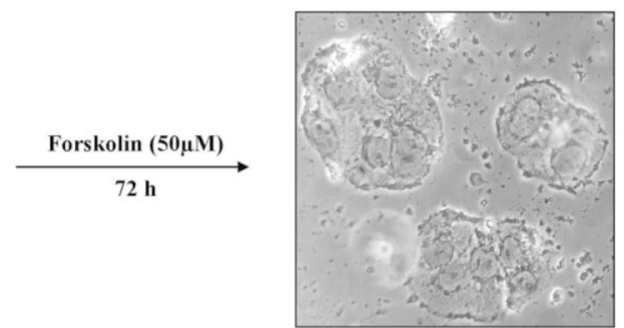

(b)

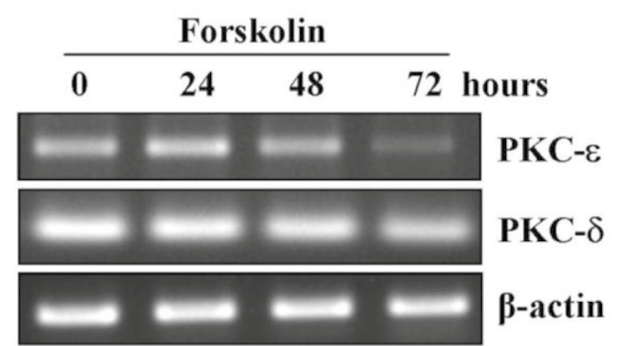

Fig. 5 Effect of forskolin on the expression of PKC- $\varepsilon$ and PKC- $\delta$ in BeWo cells. BeWo cells $\left(3 \times 10^{5}\right.$ cells/well $)$ were treated with Fo $(50 \mu \mathrm{M})$ for different time intervals. The expressions of amplified genes were analysed on $1 \%$ agarose gel and $\beta$-actin was used as a positive control and for normalization. The bar graph represents the den-

CDK4 mRNA levels were down-regulated by 10, 22 and $30 \%$ at the 24-, 48- and 72-h time points, respectively. The major tumour suppressor genes were found to be downregulated with an increase in time of exposure to Fo. p21 and p53 genes were down-regulated time dependently almost 10 and $25 \%$ at $48 \mathrm{~h}$ and showed a more than $50 \%$ decrease at $72 \mathrm{~h}$. While Rb mRNA expression decreased $10 \%$ up to $48 \mathrm{~h}$ and recorded a $60 \%$ reduction in its level compared to control. Fo induced the mRNA levels of caspase- 8 by $20 \%$ at the 24 -h time point and drastically inhibited the same at the 48 - and 72 -h time points by 10

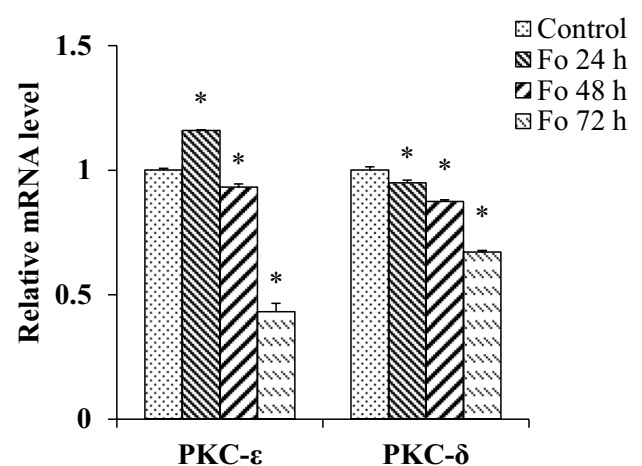

sitometric analysis of mRNA levels (mean $\pm \mathrm{SD}, n=3$ ). Differences in mRNA levels are statistically significant if $* P<0.05$ compared with the 0 -h values as analysed using one-way ANOVA followed by Tukey's post hoc test

and $45 \%$, respectively. However, caspase- 3 clearly showed 15,40 and $65 \%$ time-dependent inhibition of mRNA levels with the 24-, 48- and 72-h treatments, respectively. 
Fig. 6 Effect of forskolin on the mRNA expression of apoptotic and cell cycle regulators in BeWo cells. BeWo cells $\left(3 \times 10^{5}\right.$ cells/well) were treated with Fo $(50 \mu \mathrm{M})$ for different time intervals. The expressions of amplified genes were analysed on $1 \%$ agarose gel and $\beta$-actin was used as a positive control and for normalization. The bar graph represents the densitometric analysis of mRNA levels (mean $\pm \mathrm{SD}, n=3$ ). Differences in mRNA levels are statistically significant if $* P<0.05$ compared with the 0 -h values as analysed using one-way ANOVA followed by Tukey's post hoc test
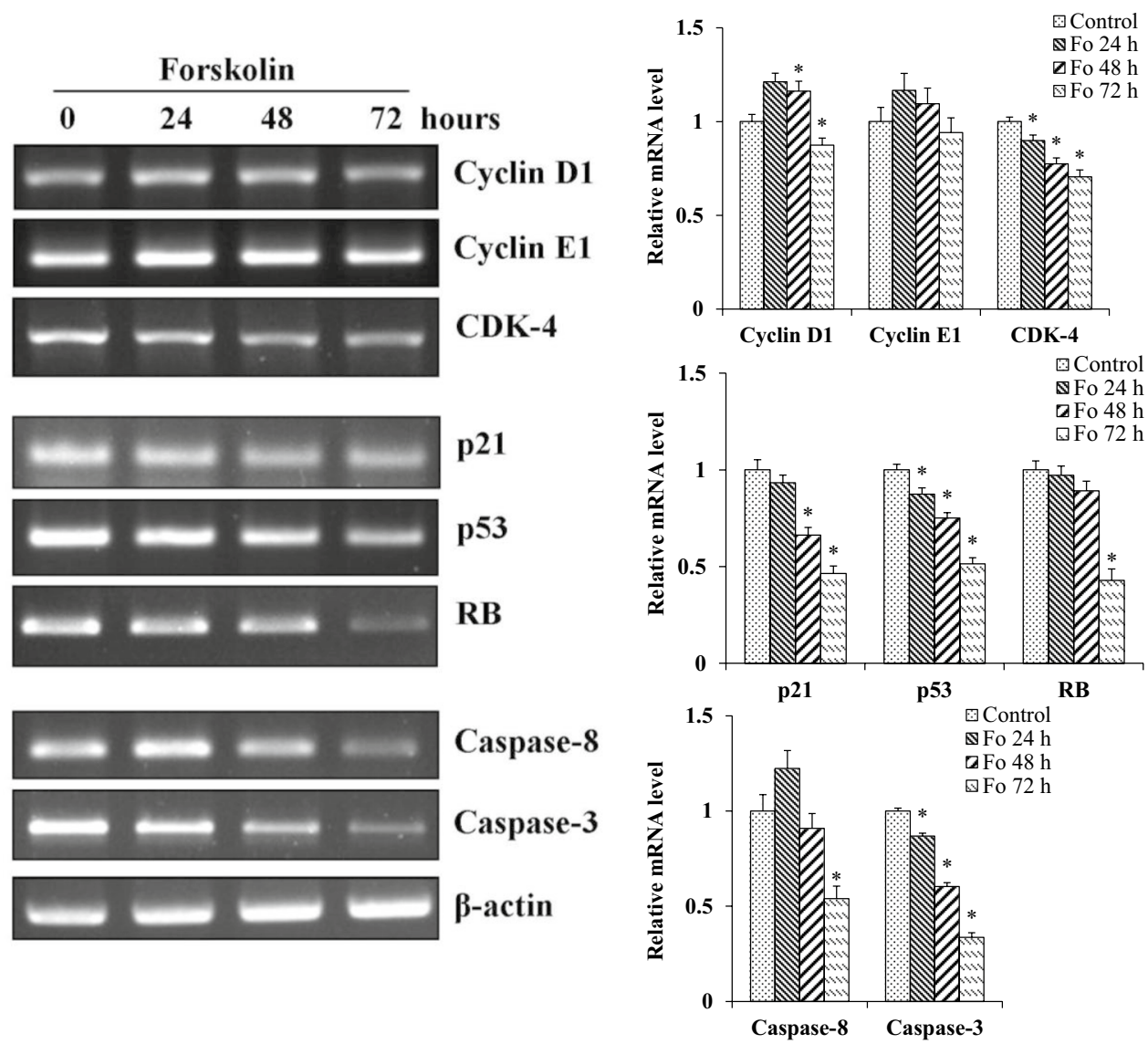

\section{Forskolin and PMA synergistically induce the hCG mRNA levels and down-regulates E-cadherin mRNA expression; and PMA induces and Fo inhibits the mRNA expression of PKC- $\varepsilon$ and PKC- $\delta$ in BeWo cells}

To study the combinatorial effect of Fo and PMA on BeWo cells, cells were treated with Fo alone, PMA alone and Fo + PMA for $72 \mathrm{~h}$ and the mRNA levels of $\alpha$-hCG, $\beta$-hCG, endoglin, E-cadherin, PKC- $\varepsilon$ and PKC- $\delta$ are analysed by RTPCR. The cells treated with Fo alone and PMA alone showed an increase in the expression of the mRNA levels of $\alpha$-hCG and $\beta$-hCG and down-regulated E-cadherin mRNA expression compared to control. However, cells treated with Fo + PMA synergistically induced the expression of both $\alpha$-hCG and $\beta$-hCG and reduced E-cadherin expression compared to the Fo- and PMA-alone treatment (Fig. 7a).PKC- $\varepsilon$ and PKC- $\delta$ show induced mRNA expression only in PMA treatment and Fo significantly decreases the above mRNA transcripts compared to control (Fig. 7b).

\section{Regulation of cell cycle regulator transcripts by Fo and PMA in BeWo cells}

To study the individual and combinatory action of PKA and PKC on mRNA expressions of apoptotic and cell cycle regulators in BeWo cells, Fo and PMA alone and in combination were treated for $72 \mathrm{~h}$ and the mRNA levels were analysed by RT-PCR. Cells treated with Fo alone decreased the cyclin D1 mRNA by $40 \%$ and the cells treated with PMA alone showed a marginal increase in cyclin D1. And the cells treated with Fo + PMA down-regulated the cyclin D1 mRNA level by more than $35 \%$ when compared to control and the expression was similar to the Fo-treated sample. However, the CDK-4 level recorded a 10\% decrease in Foand PMA-alone treatments and the combination treatment showed 20\% inhibition of CDK-4 mRNA expression compared to control. The expression of tumour suppressor genes studied here exhibited decreased expression in all the three treatments, in which Fo and PMA alone inhibit p21 expression by 33 and $38 \%$, respectively, and with the combination 
Fig. 7 Effect of forskolin and PMA on the mRNA expression of a $\alpha$-hCG, $\beta$-hCG, endoglin, E-cadherin, b PKC- $\varepsilon$ and PKC- $\delta$ in BeWo cells.

BeWo cells $\left(3 \times 10^{5}\right.$ cells/well $)$ were treated with Fo $(50 \mu \mathrm{M})$, PMA (10 nM) and Fo + PMA for $72 \mathrm{~h}$. The expressions of amplified genes were analysed on $1 \%$ agarose gel and $\beta$-actin was used as a positive control and for normalization. The bar graph represents the densitometric analysis of mRNA levels (mean $\pm \mathrm{SD}, n=3$ ). Differences in mRNA levels are statistically significant if $* P<0.05$ compared to control, ${ }^{\#} P<0.05$ compared to Fo and ${ }^{\$} P<0.05$ compared to PMA as analysed using one-way ANOVA followed by Tukey's post hoc test
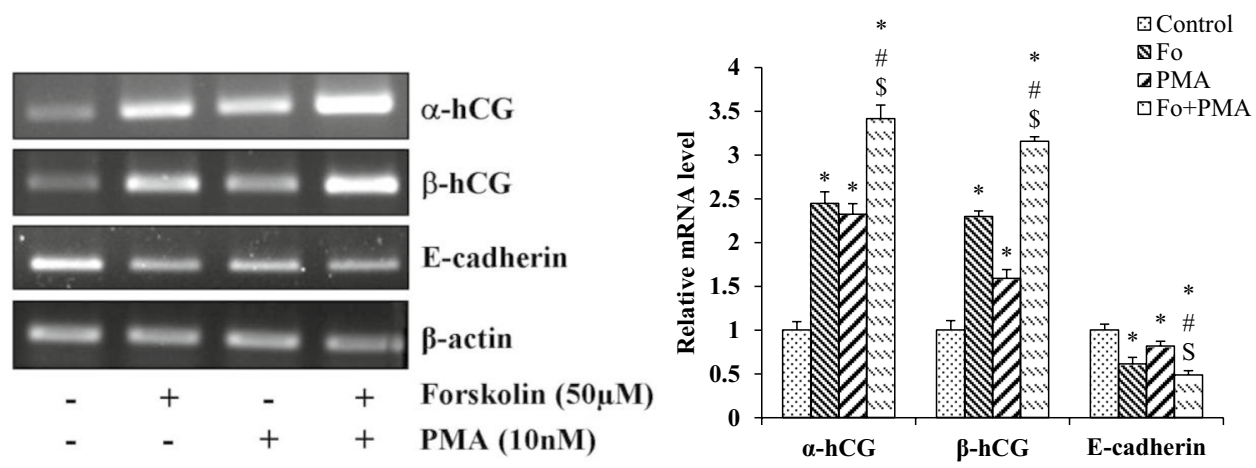

(a)
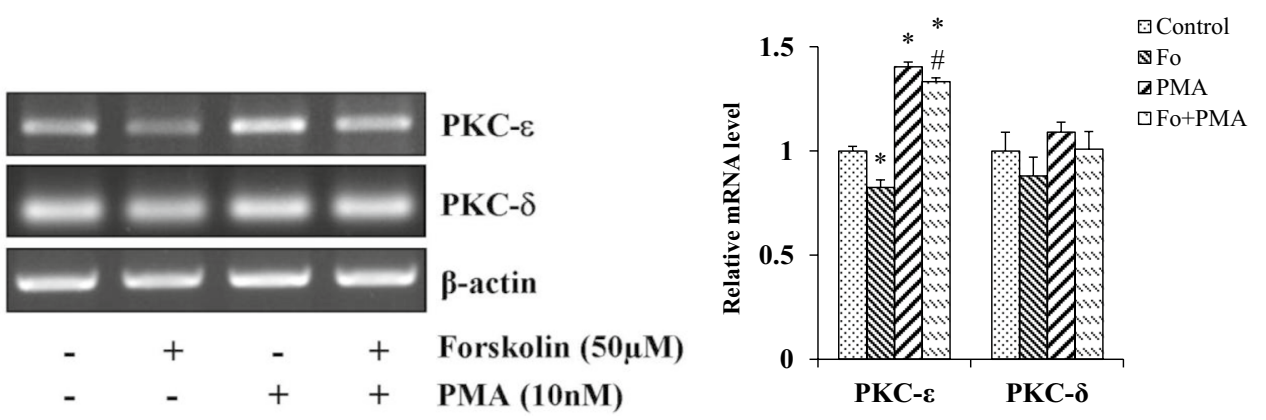

(b) treatment a 55\% decrease is observed compared to control. Also the level of p53 mRNA was decreased by 38,15 and $37 \%$, respectively, in the cells treated with Fo alone, PMA alone and Fo + PMA. Further, Fo decreases Rb mRNA levels by $53 \%$ and Fo + PMA showed only $30 \%$ inhibition; however, a marginal decrease by $10 \%$ was observed in the cells treated with PMA alone when compared to control. The mRNA level of caspase- 8 was reduced by $30 \%$ in the cells treated with Fo alone and PMA alone, and an $18 \%$ decrease was observed in the cells treated with Fo + PMA when compared to control (Fig. 8).

\section{Fo and PMA regulate protein expressions of $\beta$-hCG, PKC- $a$, E-cadherin, PCNA and Rb in BeWo cells}

Functional levels of any genes after being transcribed into protein are analysed by western blotting. The protein levels of $\beta$-hCG, PKC- $\alpha$, E-cadherin, PCNA and Rb were analysed following the treatment with Fo and PMA in BeWo cells. Cells treated with Fo for different time intervals showed decreased levels of E-cadherin, PCNA and $\mathrm{Rb}$ proteins with the increase in time (Fig. 9a). The cells treated with Fo + PMA induced the expression of $\beta$-hCG twofold compared to Fo alone and PMA increased $\beta$-hCG levels marginally compared to control. However, PKC- $\alpha$ decreased marginally in Fo treatment and a significant decrease was observed in the cells treated with PMA alone and Fo + PMA. Further, E-cadherin and Rb proteins' expressions were down-regulated significantly in the cells treated with Fo alone and PMA alone, while in in the cells treated with Fo + PMA both proteins are inhibited with negligible expressions. The expression of PCNA protein was reduced in the cells treated with Fo alone, while there was no change observed in the PCNA protein level in the cells treated with PMA alone and Fo + PMA (Fig. 9b).

\section{Forskolin and PMA induce G2/M phase cell cycle arrest in differentiating BeWo cells}

The role of Fo and PMA in regulating cell cycle progression was studied by flow cytometry. Cells were treated with Fo alone, PMA alone and Fo + PMA for $72 \mathrm{~h}$. The cells without any treatment were considered as control. Results presented in Fig. 10 showed the DNA content of control cells with a sharp peak at the G0/G1 phase corresponding to $52.3 \%$ of cells and a slight peak with $29.2 \%$ cells at the G2/M phase. Following treatment with Fo and PMA, DNA content at the G0/G1 phase decreased to 38.8 and $40 \%$, while a gradual increase in the DNA content of 38.3 and $33.3 \%$ at the $\mathrm{G} 2 / \mathrm{M}$ phase was observed in differentiated cells. Consistent with the syncytial markers' expression, the increase in DNA content in the G2/M phase (46.8\%) and a slight peak with $28.3 \%$ at the G0/G1 phase of cell cycle demonstrate the functional regulation of differentiation by Fo and PMA in BeWo cells. 
Fig. 8 Effect of forskolin and PMA on the mRNA expression of apoptotic and cell cycle regulators in BeWo cells. BeWo cells $\left(3 \times 10^{5}\right.$ cells/well $)$ were treated with $\mathrm{Fo}(50 \mu \mathrm{M})$ and PMA (10 nM) and Fo + PMA for $72 \mathrm{~h}$. The expressions of amplified genes were analysed on $1 \%$ agarose gel and $\beta$-actin was used as a positive control and for normalization. The bar graph represents the densitometric analysis of mRNA levels (mean $\pm \mathrm{SD}, n=3$ ). Differences in mRNA levels are statistically significant if $* P<0.05$ compared to control, ${ }^{\#} P<0.05$ compared to Fo and ${ }^{\$} P<0.05$ compared to PMA as analysed using one-way ANOVA followed by Tukey's post hoc test
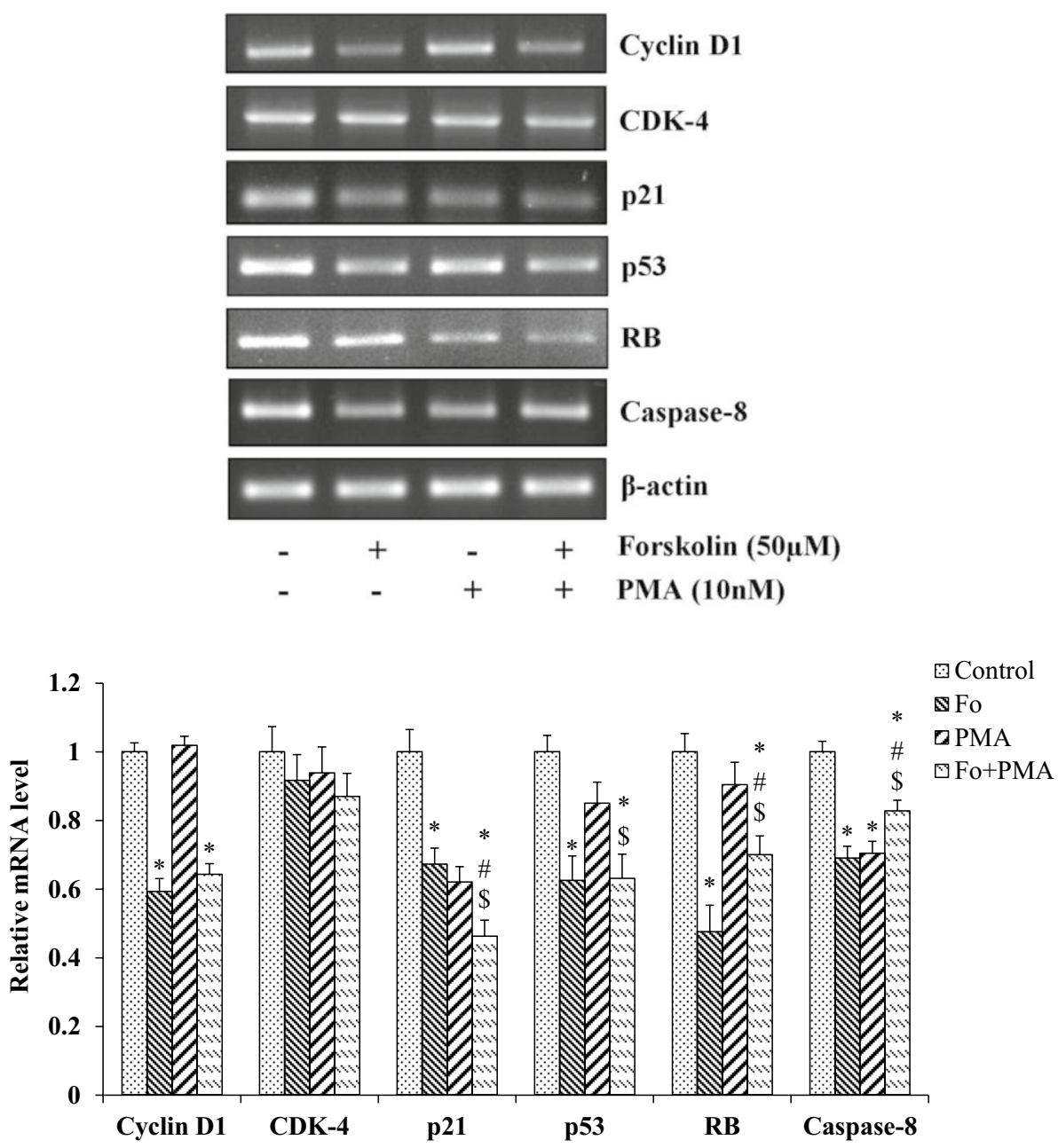

\section{Discussion}

Cancer is the multi process controlled phenomena and carcinoma derived cancers are highly prevalent malignancies causing a deadly disease. The survival rates vary dramatically among different type of cancer. Although development of targeted therapeutics has been improved in cancer treatment over the years, the harsh reality is that the "War on Cancer" still continues [50]. In the present study, human BeWo choriocarcinoma cells are used to investigate the action of PKA and PKC, the members of protein kinase superfamily which are involved in controlling the regulatory proteins. These regulatory proteins following the phosphorylation activate signal transduction cascades implicated in cellular functions and bring down the desired response. Choriocarcinoma cells are derived from the abnormal placentation and are an appropriate in vitro model system to study the factors associated with differentiation, invasion and other cellular events as an alternative of clinical samples. Initially, cell proliferation was monitored by treating the cells with different concentrations of Fo and PMA for specific time periods. The cells treated with Fo and PMA showed a decrease in their proliferation with respect to time and concentration which are concurrent with the earlier findings [51, 52], where Fo significantly reduced the proliferation of BeWo cells in a time-dependent manner and a decrease in the proliferation correlates with the growth-restricted process of cellular differentiation. In parallel, the PKA inhibitor overcomes the Fo effects, which is consistent with the available reports on PKA activation by Fo in choriocarcinoma cells which induces cytotrophoblast cell differentiation into syncytiotrophoblast. PMA decreased the cell proliferation and suggested a clear indication of the differentiation of cells with loss of proliferation as reported in leukaemia HEL and K562 cells signifying the role of steady-state maintenance of mitochondrial functions in the regulation of differentiation by PMA [53]. Further, the results of the expression level and enzymatic activity of alkaline phosphatase correlate with the progression of Fo-mediated cAMP-induced cell fusion [43].

Morphological changes observed during the treatment of cells with Fo clearly reflect the differentiation process. In association with the morphological changes, expressions 
Fig. 9 Effect of forskolin and PMA on the E-cadherin, PCNA, $\mathrm{Rb}, \beta-\mathrm{hCG}$ and PKC- $\alpha$ protein levels in BeWo cells. BeWo cells $\left(3 \times 10^{5}\right.$ cells/well $)$ were treated with Fo $(50 \mu \mathrm{M})$ for different time intervals (24, 48 and $72 \mathrm{~h}$ ). In another treatment group, cells were treated with Fo $(50 \mu \mathrm{M})$, PMA $(10 \mathrm{nM})$ and Fo + PMA for $72 \mathrm{~h}$. GAPDH was used as a positive control and for normalization. The bar graph represents the densitometric analysis of protein levels $($ mean $\pm \mathrm{SD}, n=3)$. Differences in protein levels are statistically significant if $* P<0.05$ compared to control, ${ }^{\#} P<0.05$ compared to Fo and ${ }^{\$} P<0.05$ compared to PMA as analysed using one-way ANOVA followed by Tukey's post hoc test
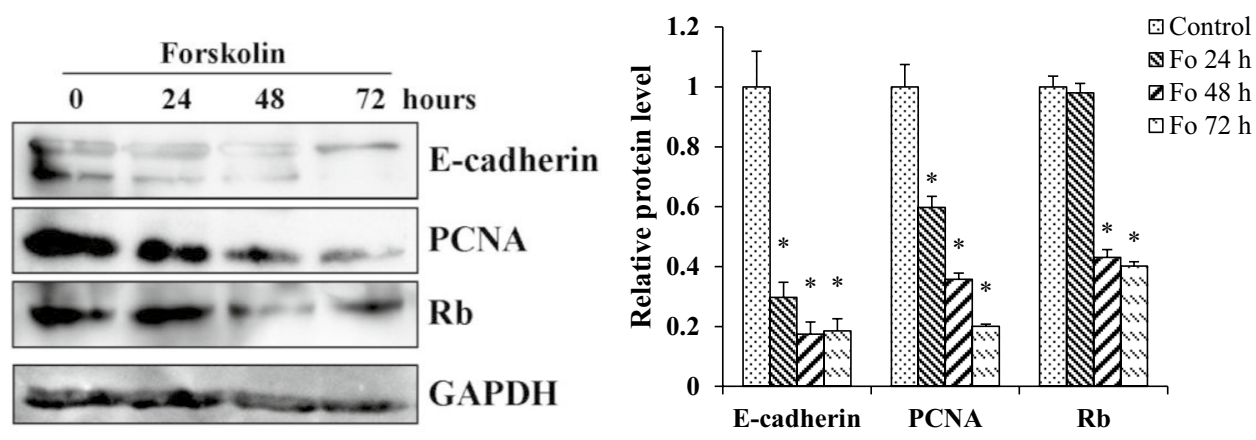

(a)

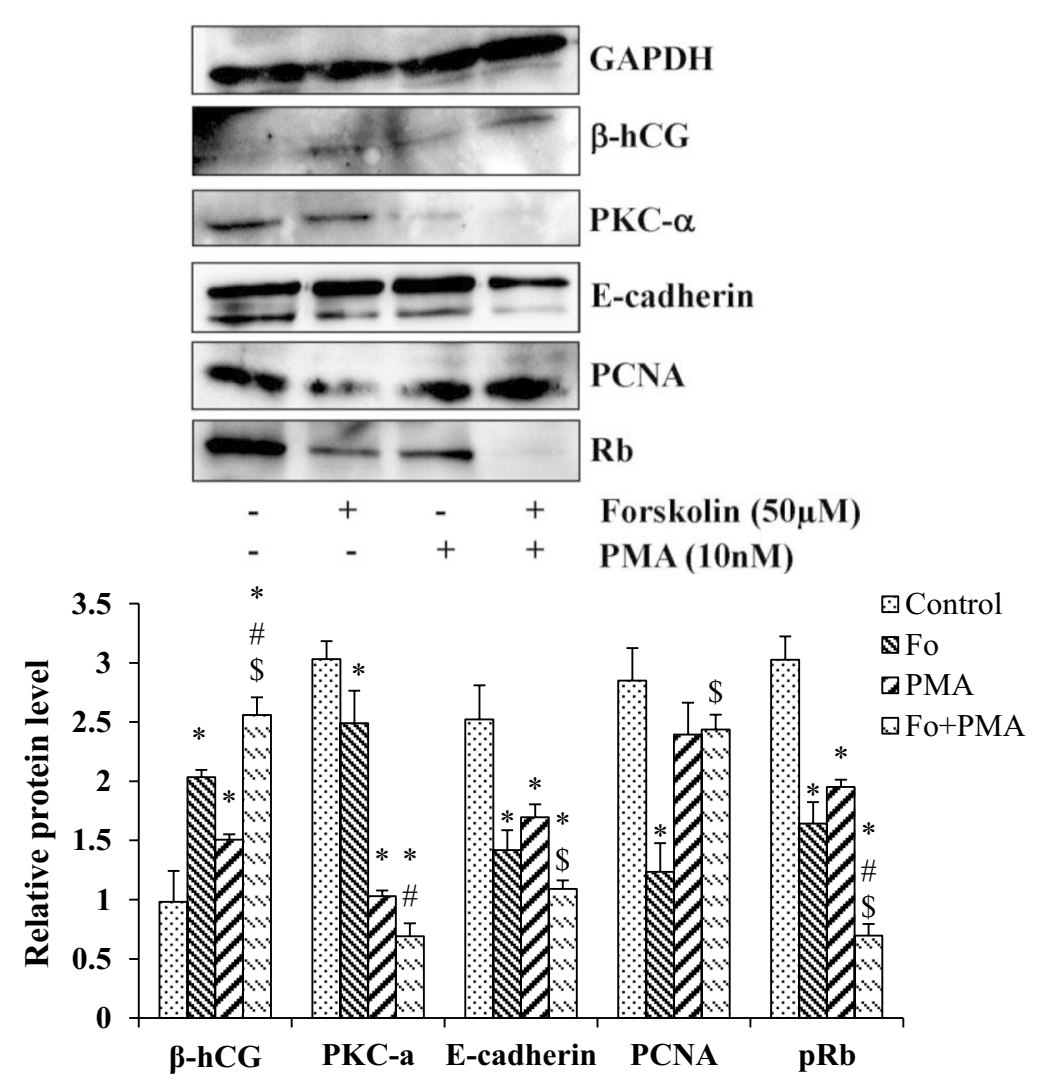

(b) of important biochemical markers of differentiation were studied. In differentiated cells, the expression of hCG was associated with a cAMP-dependent PKA pathway [24, 54] and hCG is a glycoprotein that consists of two dissimilar subunits, $\alpha$ and $\beta$ held together by non-covalent interactions. Biosynthesis of $\alpha$ subunit which is common to other glycoprotein hormones and unique subunit $\beta$-hCG in pregnant animal, placental tissue and human choriocarcinoma cell lines is extensively validated $[54,55]$. In differentiating BeWo cells, the mRNA expression of $\alpha$-hCG was induced early by $24 \mathrm{~h}$ compared to $\beta$-hCG expression which shows a clear increase in mRNA transcript over time and induced over a period of $72 \mathrm{~h}$ suggesting that the production of $\beta$-hCG is strictly dependent on syncytium formation (fusion of cells) $[51,56]$. Moreover, silencing of $\alpha / \beta-\mathrm{hCG}$ in choriocarcinoma cells decreases cell fusion via down-regulation of PKA activation establishing the significance of $\mathrm{hCG}$ in the fusion of BeWo cells [57]. In addition, endoglin, a component of TGF- $\beta$ receptor system, showed a gradual induction of its mRNA transcript in Fo-treated BeWo cells. Similarly, endoglin expressed in endothelial cells, leukemic cells and syncytiotrophoblast is validated as a distinctive differentiation marker [14, 58]. Endoglin is also found to be an active regulator of invasive pathway during human trophoblast 


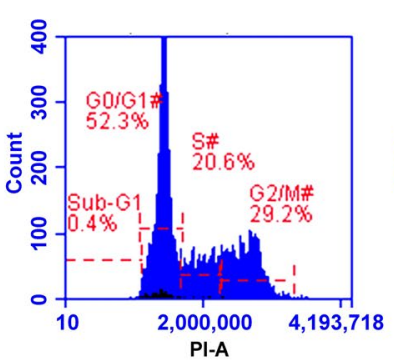

Control

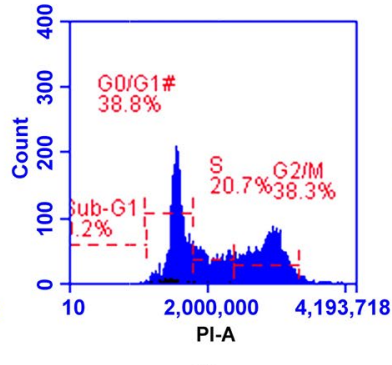

Fo

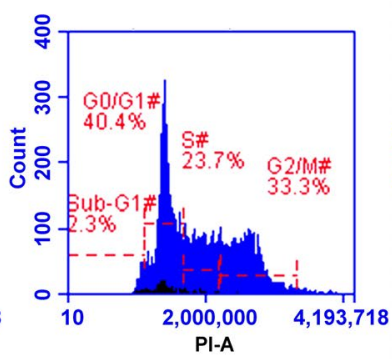

PMA

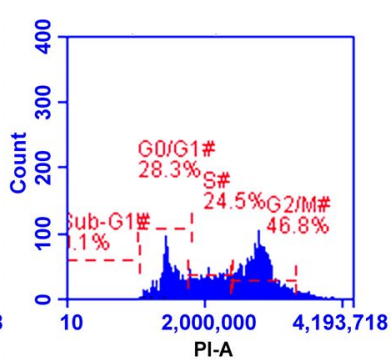

Fo+PMA

(a)

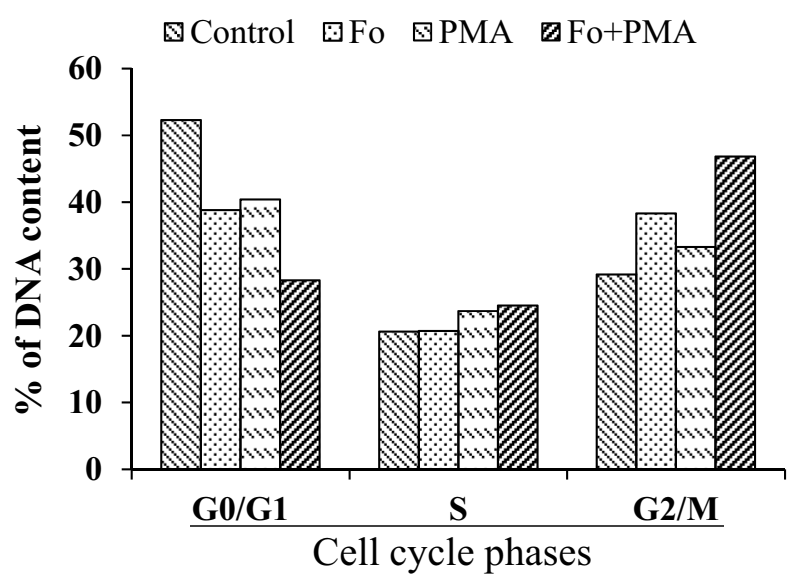

(b)

Fig. 10 Effect of forskolin and PMA on cell cycle progression in BeWo cells. BeWo cells $\left(3 \times 10^{5}\right.$ cells/well $)$ were treated with Fo $(50 \mu \mathrm{M})$, PMA $(10 \mathrm{nM})$ and Fo + PMA for $72 \mathrm{~h}$. a Flow cytometry

differentiation [59] and in agreement with the statement cadherin family of transmembrane glycoprotein E-cadherin, a cell adhesion molecule involved in differentiation and invasion, down-regulated its mRNA and protein levels in Fotreated cells progressively with an increase in time intervals. This is probably due to loss of E-cadherin on the surface of fusing cells which is mediated by cAMP in BeWo cells [16].

In some cells, the activation of the cAMP pathway leads to the inhibition of receptor-mediated phospholipase $\mathrm{C}$ (PLC) stimulation. In contrary, stimulation of PLC may activate the wide range of PKCs that affect the magnitude of cAMP response mediated via other receptors [60]. In our report, PMA up-regulates PKC- $\varepsilon$ and $\delta$ mRNA transcripts, whereas Fo alone and in combination with PMA inhibits the expression of both isoforms in differentiated cells. However, PMA fails to activate and Fo alone and in combination with PMA down-regulated PKC- $\alpha$ protein levels. These observations clearly suggest the involvement of cAMP-mediated PLC inhibition in the down-regulation of PKC isoform levels in BeWo cells. Omata et al. using BeWo cells demonstrated that cell fusion and differentiation are mediated by both analysis was performed by PI staining and $\mathbf{b}$ results were expressed as $\%$ of DNA content in different phases of cell cycle

the PKC and PKA pathways, in which the PKC pathway activated by PMA alone can induce major differentiation markers and cell fusion as in the case of Fo-PKA-mediated syncytia. The syncytium synergistically amplified when both protein kinase $\mathrm{C}$ and $\mathrm{A}$ pathways were activated together and suggests that the two parallel pathways may interact at multiple levels in the signalling cascade [41, 61]. In compliance with the earlier work, the expression of $\alpha$ - and $\beta$-hCG levels induced in Fo/PMA-mediated cell differentiation and the same mRNA transcripts were synergistically increased when the cells are activated together and the $\beta$-hCG expression attains the same status in both mRNA and protein levels [42]. Synergistic mRNA and protein levels were observed not only in the up-regulated markers but also imply with E-cadherin which is down-regulated double the time when the cells are treated with Fo or PMA alone and with the combination of Fo and PMA.

The most critical step during the transition of cells from proliferating to attaining the differentiation stage is the inhibition of DNA synthesis [62]. Accordingly, proliferating cell nuclear antigen (PCNA), an essential component 
of the cell cycle machinery that coordinates with cyclins to initiate DNA synthesis, showed decreased mRNA and protein levels in differentiated BeWo cells [63]. PCNA and cyclin expressions are rich in proliferating cancer cells and higher levels of PCNA were observed in the invasive hydatidiform mole placentae [64] and overexpression of cyclins in cancer cells correlates with the increase in malignancy [65]. These findings suggest that the intrinsic control could be a crucial factor that prevents the onset of malignancy and allows normal pregnancy to ensue. Increased expression of cyclins reflects the proliferating ability of the cells, whereas lower levels relate to differentiation [12, 23]. Increased cell numbers by Fo at 24-h treatment are in agreement with the induced expressions of cyclin D1 and cyclin E1 mRNA transcripts and their levels decreased over the next 48 and $72 \mathrm{~h}$ during which syncytialization would be occurring. PMA alone has no effect on cyclin D1 and CDK-4 mRNAs but Fo performs a similar function even in the presence of PMA [21, 40]. It was observed that there was no evidence of CDK-4 induction and its down-regulation reflects its inactivation status preceding syncytialization. Also decreased expressions of the CDK inhibitor $\mathrm{p} 21$ and the tumour suppressors p53 and $\mathrm{Rb}$ during differentiation appeared to be resistant towards apoptosis [66]. The $\mathrm{Rb}$ protein expression in Fo treatment reduced gradually following syncytia and only marginal levels were observed with PMA-treated BeWo cells. However, Rb protein levels completely diminished in the combinatorial activation of PKA and PKC but not with the transcript levels [37].

Syncytialization was associated with the increased levels of the anti-apoptotic and decreased expression of proapoptotic molecules. The present study also shows reduced levels of caspase- 3 and caspase- 8 transcripts in Fo-mediated differentiated cells. This is in agreement with the earlier results shown by Wei et al. [66]. Moreover, PMA exposure also decreased caspase- 8 mRNA transcripts and expression reflects also in combination with Fo. Altered expressions of these transcripts or proteins bring down changes in cellular functions and failure in any of the cell cycle events disrupts the nuclear content of the cells and it happens even with the differentiated cells [62]. Overall DNA content in the G0/ G1 phase reduced with progressive differentiation of cells induced by Fo/PMA and simultaneously the G2/M phase shows a dramatic increase in DNA content following syncytia in both Fo- and PMA-treated cells. Intensity of nuclear content is more in combination and suggests the G2/M phase of cell cycle arrest during differentiation. Our study provides an insight into the regulation of cell cycle players and coordinated role of protein kinases as an evidence of BeWo choriocarcinoma cell differentiation, and these agents can also be used as internal regulators in preventing cancer by differentiation therapy approach. Further, the optimization of this approach requires an improved understanding of interactions between these classes of agents in cellular functions.

Acknowledgements The authors wish to express their gratitude to the Department of Science and Technology-PURSE [SR/59/ Z-23/2010/38(c)] and University Grants Commission-CPEPA [8-2/2008(NS/PE)], Govt. of India for providing financial support. They also wish to express their gratitude to the Department of Microbiology and Biotechnology, Bangalore University, Bengaluru for providing the DST-FIST, UGC-SAP and laboratory facility. They wish to thank Prof. P. Kondaiah, Dept. of MRDG, IISc, Bengaluru for providing the flow cytometry facility. The author Naveen Kumar M., thank Prof. M. V. V. Subramanyam and Late E. Vijayalakshmi for their support during his research and greatly acknowledges the Council for Scientific and Industrial Research (CSIR), Govt. of India for the award of Senior Research Fellowship (09/039 (0116)/2016 EMR-I).

\section{Compliance with ethical standards}

Conflict of interest The authors declare that they have no conflict of interest.

\section{References}

1. Smith HO, Qualls CR, Prairie BA, Padilla LA, Rayburn WF, Key CR (2003) Trends in gestational choriocarcinoma: a 27-year perspective. Obstet Gynecol 102:978-987

2. Altieri A, Franceschi S, Ferlay J, Smith J, La Vecchia C (2003) Epidemiology and aetiology of gestational trophoblastic diseases. Lancet Oncol 4:670-678

3. Nelson DM (2015) How the placenta affects your life, from womb to tomb. Am J Obstet Gynecol 213:S12-S13. https://doi. org/10.1016/j.ajog.2015.08.015

4. Balagopal PG, Pandey M, Chandramohan K, Somanathan T, Kumar A (2003) Unusual presentation of choriocarcinoma. World J Surg Oncol 1:4-4. https://doi.org/10.1186/1477-7819-1-4

5. Stevens FT, Katzorke N, Tempfer C, Kreimer U, Bizjak GI, Fleisch MC, Fehm TN (2015) Gestational trophoblastic disorders: an update in 2015. Geburtshilfe Frauenheilkund 75:1043-1050. https://doi.org/10.1055/s-0035-1558054

6. Berkowitz RS, Goldstein DP (2009) Current management of gestational trophoblastic diseases. Gynecol Oncol 112:654-662. https ://doi.org/10.1016/j.ygyno.2008.09.005

7. Yu P, Diao W, Jiang X (2016) A successfully treated metastatic choriocarcinoma coexistent with pregnancy: a case report of a 4-year follow-up. Medicine 95:e3505. https://doi.org/10.1097/ MD.0000000000003505

8. Yaginuma Y, Yamashita T, Takuma N, Katayama H, Ishikawa M (1995) Analysis of the p53 gene in human choriocarcinoma cell lines. Br J Cancer 71:9-12

9. Kobayashi Y, Banno K, Shimizu T, Ueki A, Tsuji K, Masuda K, Kisu I, Nomura H, Tominaga E, Nagano O, Saya H, Aoki D (2013) Gene expression profile of a newly established choriocarcinoma cell line, iC3-1, compared to existing choriocarcinoma cell lines and normal placenta. Placenta 34:110-118. https://doi. org/10.1016/j.placenta.2012.11.003

10. Kaufmann P, Black S, Huppertz B (2003) Endovascular trophoblast invasion: implications for the pathogenesis of intrauterine growth retardation and preeclampsia. Biol Reprod 69:1-7. https ://doi.org/10.1095/biolreprod.102.014977

11. Bamberger AM, Bamberger CM, Aupers S, Milde-Langosch K, Loning T, Makrigiannakis A (2004) Expression pattern of 
the activating protein-1 family of transcription factors in the human placenta. Mol Hum Reprod 10:223-228. https://doi. org/10.1093/molehr/gah011

12. Neelima PS, Rao AJ (2008) Gene expression profiling during Forskolin induced differentiation of BeWo cells by differential display RT-PCR. Mol Cell Endocrinol 281:37-46. https://doi. org/10.1016/j.mce.2007.10.002

13. Kliman HJ, Nestler JE, Sermasi E, Sanger JM, Strauss JF 3rd (1986) Purification, characterization, and in vitro differentiation of cytotrophoblasts from human term placentae. Endocrinology 118:1567-1582. https://doi.org/10.1210/endo-118-4-1567

14. Letamendia A, Lastres P, Almendro N, Raab U, Buhring HJ, Kumar S, Bernabeu C (1998) Endoglin, a component of the TGF-beta receptor system, is a differentiation marker of human choriocarcinoma cells. Int J Cancer 76:541-546

15. Webb PD, Todd J (1988) Attachment of human placental-type alkaline phosphatase via phosphatidylinositol to syncytiotrophoblast and tumour cell plasma membranes. Eur J Biochem 172:647-652

16. Coutifaris C, Kao LC, Sehdev HM, Chin U, Babalola GO, Blaschuk OW, Strauss JF 3rd (1991) E-cadherin expression during the differentiation of human trophoblasts. Development 113:767-777

17. Chen YX, Allars M, Maiti K, Angeli GL, Abou-Seif C, Smith R, Nicholson RC (2011) Factors affecting cytotrophoblast cell viability and differentiation: evidence of a link between syncytialisation and apoptosis. Int J Biochem Cell Biol 43:821-828. https://doi.org/10.1016/j.biocel.2011.02.007

18. Knerr I, Schubert SW, Wich C, Amann K, Aigner T, Vogler T, Jung R, Dotsch J, Rascher W, Hashemolhosseini S (2005) Stimulation of GCMa and syncytin via cAMP mediated PKA signaling in human trophoblastic cells under normoxic and hypoxic conditions. FEBS Lett 579:3991-3998. https://doi. org/10.1016/j.febslet.2005.06.029

19. Ji L, Brkic J, Liu M, Fu G, Peng C, Wang YL (2013) Placental trophoblast cell differentiation: physiological regulation and pathological relevance to preeclampsia. Mol Asp Med 34:9811023. https://doi.org/10.1016/j.mam.2012.12.008

20. Lapenna S, Giordano A (2009) Cell cycle kinases as therapeutic targets for cancer. Nat Rev Drug Discov 8:547-566. https://doi. org/10.1038/nrd2907

21. Bononi A, Agnoletto C, De Marchi E, Marchi S, Patergnani S, Bonora M, Giorgi C, Missiroli S, Poletti F, Rimessi A, Pinton $\mathrm{P}$ (2011) Protein kinases and phosphatases in the control of cell fate. Enzyme Res. https://doi.org/10.4061/2011/329098

22. Hanahan D, Weinberg RA (2000) The hallmarks of cancer. Cell 100:57-70

23. Nurse P (2000) A long twentieth century of the cell cycle and beyond. Cell 100:71-78

24. Wice B, Menton D, Geuze H, Schwartz AL (1990) Modulators of cyclic AMP metabolism induce syncytiotrophoblast formation in vitro. Exp Cell Res 186:306-316

25. Gottesman MM, Fleischmann RD (1986) The role of cAMP in regulating tumour cell growth. Cancer Surv 5:291-308

26. Mukherjee A, Park-Sarge OK, Mayo KE (1996) Gonadotropins induce rapid phosphorylation of the $3^{\prime}, 5^{\prime}$-cyclic adenosine monophosphate response element binding protein in ovarian granulosa cells. Endocrinology 137:3234-3245

27. Stork PJ, Schmitt JM (2002) Crosstalk between cAMP and MAP kinase signaling in the regulation of cell proliferation. Trends Cell Biol 12:258-266

28. Richards JS (2001) New signaling pathways for hormones and cyclic adenosine $3^{\prime}, 5^{\prime}$-monophosphate action in endocrine cells. Mol Endocrinol 15:209-218
29. Sevetson BR, Kong X, Lawrence JC Jr (1993) Increasing cAMP attenuates activation of mitogen-activated protein kinase. Proc Natl Acad Sci U S A 90:10305-10309

30. D'Angelo G, Lee H, Weiner RI (1997) cAMP-dependent protein kinase inhibits the mitogenic action of vascular endothelial growth factor and fibroblast growth factor in capillary endothelial cells by blocking Raf activation. J Cell Biochem 67:353-366

31. Chen J, Iyengar R (1994) Suppression of Ras-induced transformation of NIH 3 T3 cells by activated G alpha s. Science 263:1278-1281

32. Thoresen GH, Johasen EJ, Christoffersen T (1999) Effects of cAMP on ERK mitogen-activated protein kinase activity in hepatocytes do not parallel the bidirectional regulation of DNA synthesis. Cell Biol Int 23:13-20. https://doi.org/10.1006/cbir.1998.0314

33. Steinberg SF (2008) Structural basis of protein kinase C isoform function. Physiol Rev 88:1341-1378

34. Parekh DB, Ziegler W, Parker PJ (2000) Multiple pathways control protein kinase $\mathrm{C}$ phosphorylation. EMBO J 19:496-503. https ://doi.org/10.1093/emboj/19.4.496

35. Kharbanda S, Saleem A, Emoto Y, Stone R, Rapp U, Kufe D (1994) Activation of Raf-1 and mitogen-activated protein kinases during monocytic differentiation of human myeloid leukemia cells. J Biol Chem 269:872-878

36. He H, Wang X, Gorospe M, Holbrook NJ, Trush MA (1999) Phorbol ester-induced mononuclear cell differentiation is blocked by the mitogen-activated protein kinase kinase (MEK) inhibitor PD98059. Cell Growth Differ 10:307-315

37. Leszczyniecka M, Roberts T, Dent P, Grant S, Fisher PB (2001) Differentiation therapy of human cancer: basic science and clinical applications. Pharmacol Ther 90:105-156

38. Frey MR, Saxon ML, Zhao X, Rollins A, Evans SS, Black JD (1997) Protein kinase C isozyme-mediated cell cycle arrest involves induction of p21(waf1/cip1) and p27(kip1) and hypophosphorylation of the retinoblastoma protein in intestinal epithelial cells. J Biol Chem 272:9424-9435

39. Nakagawa M, Oliva JL, Kothapalli D, Fournier A, Assoian RK, Kazanietz MG (2005) Phorbol ester-induced G1 phase arrest selectively mediated by protein kinase $\mathrm{C}$ delta-dependent induction of p21. J Biol Chem 280:33926-33934. https://doi. org/10.1074/jbc.M505748200

40. Black JD (2000) Protein kinase C-mediated regulation of the cell cycle. Front Biosci 5:D406-D423. https://doi.org/10.2741/A522

41. Suzuki T, Ino K, Kikkawa F, Uehara C, Kajiyama H, Shibata K, Mizutani S (2002) Neutral endopeptidase/CD10 expression during phorbol ester-induced differentiation of choriocarcinoma cells through the protein kinase $\mathrm{C}$ - and extracellular signal-regulated kinase-dependent signalling pathway. Placenta 23:475-482. https ://doi.org/10.1053/plac.2002.0820

42. Andersen B, Milsted A, Kennedy G, Nilson JH (1988) Cyclic AMP and phorbol esters interact synergistically to regulate expression of the chorionic gonadotropin genes. J Biol Chem 263:15578-15583

43. Orendi K, Gauster M, Moser G, Meiri H, Huppertz B (2010) The choriocarcinoma cell line BeWo: syncytial fusion and expression of syncytium-specific proteins. Reproduction 140:759-766. https ://doi.org/10.1530/REP-10-0221

44. Mosmann T (1983) Rapid colorimetric assay for cellular growth and survival: application to proliferation and cytotoxicity assays. J Immunol Methods 65:55-63

45. Bradford MM (1976) A rapid and sensitive method for the quantitation of microgram quantities of protein utilizing the principle of protein-dye binding. Anal Biochem 72:248-254

46. Garcia-Rozas C, Plaza A, Diaz-Espada F, Kreisler M, MartinezAlonso C (1982) Alkaline phosphatase activity as a membrane marker for activated B cells. J Immunol 129:52-55 
47. Sharma SC, Clemens JW, Pisarska MD, Richards JS (1999) Expression and function of estrogen receptor subtypes in granulosa cells: regulation by estradiol and forskolin. Endocrinology 140:4320-4334

48. Patil RH, Babu RL, Naveen Kumar M, Kiran Kumar KM, Hegde SM, Ramesh GT, Chidananda Sharma S (2015) Apigenin inhibits PMA-induced expression of pro-inflammatory cytokines and AP-1 factors in A549 cells. Mol Cell Biochem 403:95-106. https ://doi.org/10.1007/s11010-015-2340-3

49. Boulaiz H, Prados J, Melguizo C, Garcia AM, Marchal JA, Ramos JL, Carrillo E, Velez C, Aranega A (2003) Inhibition of growth and induction of apoptosis in human breast cancer by transfection of gef gene. Br J Cancer 89:192-198. https://doi.org/10.1038/ sj.bjc. 6601064

50. Miller MJ, Foy KC, Kaumaya PT (2013) Cancer immunotherapy: present status, future perspective, and a new paradigm of peptide immunotherapeutics. Discov Med 15:166-176

51. Nampoothiri LP, Neelima PS, Rao AJ (2007) Proteomic profiling of forskolin-induced differentiated BeWo cells: an in-vitro model of cytotrophoblast differentiation. Reprod Biomed 14:477-487

52. Al-Nasiry S, Spitz B, Hanssens M, Luyten C, Pijnenborg R (2006) Differential effects of inducers of syncytialization and apoptosis on BeWo and JEG-3 choriocarcinoma cells. Hum Reprod 21:193201. https://doi.org/10.1093/humrep/dei272

53. Huang R, Zhao L, Chen H, Yin RH, Li CY, Zhan YQ, Zhang JH, Ge CH, Yu M, Yang XM (2014) Megakaryocytic differentiation of K562 cells induced by PMA reduced the activity of respiratory chain complex IV. PLoS ONE 9:e96246. https://doi.org/10.1371/ journal.pone.0096246

54. Pierce JG, Parsons TF (1981) Glycoprotein hormones: structure and function. Annu Rev Biochem 50:465-495. https://doi. org/10.1146/annurev.bi.50.070181.002341

55. Sharma SC, Rao AJ (1995) Secretion is a stimulus for the synthesis of human chorionic gonadotrophin by first trimester human placenta. Biochem Mol Biol Int 36:1235-1241

56. Leisser C, Saleh L, Haider S, Husslein H, Sonderegger S, Knofler M (2006) Tumour necrosis factor-alpha impairs chorionic gonadotrophin beta-subunit expression and cell fusion of human villous cytotrophoblast. Mol Hum Reprod 12:601-609. https://doi. org/10.1093/molehr/gal066

57. Malhotra SS, Suman P, Gupta SK (2015) Alpha or beta human chorionic gonadotropin knockdown decrease BeWo cell fusion by down-regulating PKA and CREB activation. Sci Rep 5:11210. https://doi.org/10.1038/srep11210

58. Gougos A, St Jacques S, Greaves A, O'Connell PJ, d'Apice AJ, Buhring HJ, Bernabeu C, van Mourik JA, Letarte M (1992) Identification of distinct epitopes of endoglin, an RGD-containing glycoprotein of endothelial cells, leukemic cells, and syncytiotrophoblasts. Int Immunol 4:83-92

59. Caniggia I, Taylor CV, Ritchie JW, Lye SJ, Letarte M (1997) Endoglin regulates trophoblast differentiation along the invasive pathway in human placental villous explants. Endocrinology 138:4977-4988. https://doi.org/10.1210/endo.138.11.5475

60. Kvanta A, Fredholm BB (1993) Synergistic effects between protein kinase $\mathrm{C}$ and cAMP on activator protein- 1 activity and differentiation of PC-12 pheochromocytoma cells. J Mol Neurosci 4:205-214. https://doi.org/10.1007/bf02821552

61. Omata W, Ackerman WE, Vandre DD, Robinson JM (2013) Trophoblast cell fusion and differentiation are mediated by both the protein kinase $\mathrm{C}$ and a pathways. PLoS ONE 8:e81003. https ://doi.org/10.1371/journal.pone.0081003

62. Uehara C, Ino K, Suzuki T, Kajiyama H, Kikkawa F, Nagasaka T, Mizutani S (2001) Upregulation of neutral endopeptidase expression and enzymatic activity during the differentiation of human choriocarcinoma cells. Placenta 22:540-549. https://doi. org/10.1053/plac.2001.0694

63. Rama S, Petrusz P, Rao AJ (2004) Hormonal regulation of human trophoblast differentiation: a possible role for 17beta-estradiol and GnRH. Mol Cell Endocrinol 218:79-94. https://doi.org/10.1016/j. mce.2003.12.016

64. Kale A, Soylemez F, Ensari A (2001) Expressions of proliferation markers (Ki-67, proliferating cell nuclear antigen, and silver-staining nucleolar organizer regions) and of $\mathrm{p} 53$ tumor protein in gestational trophoblastic disease. Am J Obstet Gynecol 184:567-574. https://doi.org/10.1067/mob.2001.111243

65. Babu RL, Naveen Kumar M, Patil RH, Devaraju KS, Ramesh GT, Sharma SC (2013) Effect of estrogen and tamoxifen on the expression pattern of AP-1 factors in MCF-7 cells: role of c-Jun, c-Fos, and Fra-1 in cell cycle regulation. Mol Cell Biochem 380:143151. https://doi.org/10.1007/s11010-013-1667-x

66. Wei B, Xu C, Rote N (2012) Increased resistance to apoptosis during differentiation and syncytialization of BeWo choriocarcinoma cells. Adv Biosci Biotechnol 3:805-813. https://doi.org/10.4236/ abb.2012.326100 